\title{
«The shadows of no man's land». Crossing the border in the divided capital of Nicosia, Cyprus
}

\author{
Freerk Boedeltje, Henk van Houtum, Olivier Thomas \\ Kramsch, Nijmegen
}

\begin{abstract}
"[I]n spite of progress made in cross-cultural scholarship in the past few decades, there remains a tendency to view the non-West either as a residual category or as an exotic organism resisting comparison. A perspective that can advance such categories as coriental despotism) and coriental mode of production can equally well embrace the notion of an coriental citys existing beyond history and analysis» (Brown 1973: 18).
\end{abstract}

\section{Introduction}

The Republic of Cyprus has been a member-state of the European Union (EU) since May 2004. Since 1974 it is divided by a UN patrolled buffer zone running from west to east, straight through the city centre of its capital, Nicosia. Greek and Turkish Cypriots have lived here in a tenuous state of cease-fire since the UN stepped in to settle the conflict that had arisen due to an attempted coup to unite the island, which led to the subsequent invasion of the northern half of the island by Greece and Turkey. From that point on, contact between Greek and Turkish Cypriot communities was almost impossible. In April 2003, the buffer zone (or Green Line) was unexpectedly opened, propelled by the prospect of EU accession of Cyprus. On May 1, 2004, however, only Greek Cyprus joined the EU. As the EU regards the Greek Cyprus authority as the sole authority on the island, the EU accession papers were settled and ratified in the name of the Republic of Cyprus only. After two years of EU membership, the Republic of Cyprus is seen as a positive construct by the people of Northern Cyprus, however, perhaps not in a manner Europe or the Greek Cypriot authorities originally planned. Northern Cyprus has been able to benefit from the European Common Market through the grey zone that the acquis communautaire allows for. After nearly three years of free movement, people interact; more specifically, they mainly work and shop on the "other» side. However, in official discourse, Nicosia is still seen as a divided city and with the deadlock on Turkish EU accession talks it will probably remain so in the near future.

Within the EU today, there is no other urban area that offers as vivid an example of inter-cultural con- flict, adaptation and exchange between a putative «east» and «west» as in Nicosia. This fact is exploited in countless tourist brochures and related publicity, with Nicosia referring to itself somewhat selfconfidently as «the last divided capital in Europe». Despite its current partitioning, Nicosia today may be understood as a "palimpsest» (GRUNDY-WARR 2002: 219), whereby older spatial patterns of colonial rule have entered into complex and multi-layered discourse with the Cypriot present. This is particularly evident on both sides of the Green Line in contemporary attempts at economic reform, EU membership, adaptation and modernization. In this article, the Nicosian palimpsest is explored through a description of the daily irregularities of a contemporary city border in this last divided capital of the European Union.

\section{A «lie» called Cyprus}

Cyprus is a clearly defined entity located squarely on the crossroads between Europe and Asia, between the western and non-western world. The coastline on Greek Cyprus embraces everything that is connected to the European, to that which is international, «turbocapitalistic» and touristic, while siphoning out capital and knowledge. The coastline on Turkish Cyprus receives «invisible» people and products, invisible in the sense that in the north, there is no agreement about what the political space should be referred to as Turkish, Northern Cyprian (legal title) or as the Turkish Republic of Northern Cyprus (TRNC) (inofficial title). Nonetheless, this invisible territory is accessible to everyone. It is a confusing space, and although physically constructed of the same minerals as the south, it has a totally different meaning on this part of the island.

O' Toole (1997: 4) writes about «the lie of the land; in the sense that the people and the land are no longer co-terminous». In the case of Cyprus, it is suggested here that its history of division has had a similar effect on it. Postcolonial independence and the evolving conflict and division detached the people from their physical and mental land. Cyprus never managed to create a national consciousness as an expression of a national culture, it turned towards the past, resulting in current events being experienced differently within the two civil societies (FANON 1961). 


\section{No man's land}

From the Greek Cypriot airport in Larnaca, it takes less than an hour to complete the 56-kilometre ride to downtown Nicosia, the capital of Cyprus, a city with nearly 200'000 inhabitants. The Greek Cypriot urban milieu may be cosmopolitan, yet at a microscale, society is still essentially colonial, reflecting the impact made by Cyprus' last colonial empire, Great-Britain. Life in Nicosia is busy, trendy and in a systematic rush. The atmosphere in this part of the city is international. The uniform-styled shops and restaurants of the main shopping street, Ledra Street, within the walls of the old city, end suddenly and surreally at a barbed-wire military wall: Nicosia's Green Line. This in-between zone, dead zone, or no man's land has led to a peculiar situation: two cities with their main centres in the outskirts and the outskirts in the centre snuffed out by a ceasefire line. When observing the fragments of Nicosia, it becomes clear that it is impossible to put all the pieces together in an attempt to grasp the whole picture, as there is none. Nicosia is not one but two, as much as there are now also two versions of Cyprus.

The old city of Nicosia is promoted in the tourist brochures as a beautiful district with many historical relics. Although the adverts mention its unique Venetian Walls, built in 1570 to protect the city from the Ottomans, no mention is made of the UN buffer zone dividing the old town in two, nor of the community existing on the other side. This disregard of the current wall of separation, or of the Cyprus conflict as a whole, is not something peculiar to hotel brochures, tourist information, maps and travel agencies alone. In the southern part of the city, every single official map of the city stops at the Green Line. To its north, a whole part of the city is denied contemporary existence. It is a place where the streets have no name, an area denoted as «non-accessible because of Turkish occupation». For the official Greek Cypriot authorities, the occupied territory ultimately represents a denial of Turkish Cypriot civil society as an integrated territorial part on the island.

This form of denial seems completely illogical, even absurd for tourists, foreigners and researchers, who find it impossible to ignore the presence of a dead space that exists and is tangible, both physically and mentally. However, in the everyday reality of the Cypriots this appears to be different. The division has become embedded within Cypriot society through the actions of the past. Its effects are not only reflected in a distorted self-image, as observed in the inability of people to characterise what it means to be a Cypriot, but also implicates a complete and ongoing institutionalisation of the Green Line. Consequently, with every attempt taken to resolve the situation, a solution seems further away and the institutionalisation of a culture of denial one step closer (O'Toole 1990). This culture of denial may be seen today in official geopolitical disputes. The Cyprus problem has become a breakpoint issue for EU accession talks with Turkey. On the one hand, Turkey is not willing to ratify the EU customs' treaty and open its ports and airports to the Republic of Cyprus, because it does not recognize the Cypriot administration. On the other hand, it is insisting that international sanctions against Northern Cyprus be loosened. Today, at least, if judging by official discourse, unification seems further away then ever before.

Mr Talat, Prime Minister of the Turkish Cypriot authority, for example, recently claimed that

"[t]he Greek Cypriots are not acting like an EU country.

They are not trying to compromise or give any rights to the Turkish Cypriots. Unfortunately, the EU is not acting in a proper way to preclude these ill intentions» (BAHCELI 2005).

According to the Turkish Cypriots, the assistance and aid promised after the accession of the Republic of Cyprus has not ended their isolated position. This appears to be particularly apparent in aid package discussions and in the dissatisfactory results of the Green Line Regulations agreement (BAHCELI 2005). On the other hand, the Greek Cypriot authorities repeatedly accuse their Turkish Cypriot counterparts for not contributing towards finding a satisfactory solution for the Cyprus problem, as is exemplified in the press release of June 19, 2006:

«If there is a justification for Mr Talat's weakness to control his political actions, there is no justification for his weakness to control his political speech. His latest remarks about an insane and comical policy of President Papadopoulos on the Cyprus issues have exceeded every limit. If these statements are not a result of embarrassment and confusion on his part, then they are simply a reaffirmation of his intransigence and his unwillingness to cooperate on finding a mutually acceptable solution to the Cyprus problem» (Republic of Cyprus 2006).

As a commentator of the Cyprus Mail wrote:

«Unfortunately, it's 40 years down the line and we are still behaving with the same narrow-mindedness that led us to this sad state of affairs in the first place. Instead of looking to the future and seeking to escape this dead end, we play the semantics game and squabble over meaningless things, searching for excuses to perpetuate the current division. $[\ldots]$ this is because our politicians build their careers on perpetuating partition» (CYprus MAIL 2006).

The ongoing geopolitical institutionalisation of the Green Line signifies the portrayal of large swathes of Middle and Near Eastern cityscape as privileged 
theatre for the conjunction of insecurity and conflict (Graham 2004; Gregory 2004). It addresses a side of modernity which, for the most part, has been neglected until now in a literature largely devoted to extolling the progressive and cosmopolitan values attached to urban life in the world's cities (ABU-Lughod 1999; SANDERCOCK 1998; SASSEN 2001; SoJa 2000). This hypothesis of a mutually constitutive relationship between cities of conflict and political nationalistic deadlock is an intriguing one. In this context, it seems that the current re-focus of urban studies around the «hidden planning history» of place annihilation and the installation of a dead zone in a city - aptly coined «urbicide» (Graham 2004: 34) - relies on the broad sweep of theoretical generalization to make its claims ultimately meaningless. Cities should not be regarded as merely passive containers for the social relations of conflict but as both their medium and prerequisite. In reality, a «dead zone» is never dead. It would seem that the paths and journeys of the contemporary shadows of the no man's land in divided cities, such as Nicosia, resist or go beyond official geopolitical rhetoric and are continuously changing. Certainly, in the light of the current deadlock in the Cyprus issue and the EU accession talks of Turkey, it is necessary to see the vitality, vividness and activity surrounding the Green Line that in political discourse is reasoned away. It is argued here for greater acknowledgement of daily minor, yet vital, changes in routines, journeys and habits linked to the crossing of the Green Line, to the voices unheard, to the shadows of the no man's land.

\section{Crossing the Green Line}

In April 2003, in the run up to the EU accession talks planned for Cyprus in 2004, the border was opened for the first time since 1974, allowing people to travel via a border checkpoint from north to south and vice versa. In the first months after the opening, thousands crossed, either out of curiosity or to meet with forgotten friends, either to see the places they had to leave or give up after the events of the 1960s and 1970s, or to feel a sense of reconciliation. The main checkpoint in Nicosia at Ledra Palace is only accessible by foot. According to official statistics, by the end of 2004, a total of 2,347,792 Greek Cypriots and 3,595,979 Turkish Cypriots had crossed the checkpoints since the time of their opening in April 2003. The latter crossed over to the south predominantly on weekdays, mainly to work, while Greek Cypriots tended to travel north on weekends to shop or sightsee (Hazou 2005). The figures, however, also indicate that many Cypriots from both sides of the Green Line did not cross; some because of their anger, some out of protest against the need to show their passports on their own island, others because of their unwillingness to forgive. The terminology used by the Greek Cypriot officials to describe border movement illustrates vividly current attitudes: the Turkish Cypriots do not cross the Green Line, but «enter» the «free areas», as if to imply that they are «outlaws», persons beyond (international) law living in restricted, non-free areas. The Greek Cypriots on the other hand «travel» to the «occupied» areas and «cross» the Green Line.

On August 10, 2004, shortly after the EU accession of Cyprus, the Green Line Regulation became fully operational. Subsequently, traffic of commodities from northern to southern Cyprus was restricted or partially deregulated (EUROPEAN COMMISSION (COM) 2005). As a result, border traffic increased steadily, mainly from north to south. With the increase came an observable change in crossing intention. People were suddenly able to buy goods that had not been available to them before. They were able to participate in European commercial markets and buy consumer goods which they could take back with them to the north. On a larger scale, people started trading. The volume and value of the goods that crosses the line remains small scale and rather limited but it is nonetheless on the increase. The amount of goods that crossed the line officially between April 2004 and April 2005 totals to just over one million Euros (European Commission (COM) 2005). Vegetables, stone products, paper goods, and furniture are the main commodities. The destination of the goods is without exception Greek Cyprus, an indication that there is no direct trade between Northern Cyprus and the EU via the Green Line.

Undoubtedly, the principal change in the nature of the crossings is labour-oriented, with an ever increasing amount of Turkish Cypriots working in Greek Cyprus as cheap labour. Everyday, thousands cross the Green Line to be picked up by Greek Cypriot companies catering for construction and related sectors. In 2004, an estimated $£ 40$ million was paid to Turkish Cypriot employees in the south and this doubled to $£ 85$ million in 2005. According to Hazou (2005), the average Turkish Cypriot wage increased by $\$ 3,000$ per annum in 2004. Similarly, the Minister of Finance of the Turkish Cypriot Administration, Mr Deniz, claimed that earnings from Turkish Cypriots working in the south contributed largely to the general increase in Turkish Cypriot salaries. Estimated figures on the number of Turkish Cypriots working in the south range from 3,000 to 8,000 (BAHCELI 2004). The average earnings of Turkish Cypriots working in the south are estimated around $£ 8,000$ per year. In contrast, the average income of people employed in Northern Cyprus is $£ 3,500$, despite the increase of wages in the past years (Hazou 2005). 
Besides the officially documented crossings, it has become increasingly clear that the Green Line is also used for illegal trafficking of people. Despite the controls carried out on both sides, illegal routes exist predominantly in the northern, more rural part of the buffer zone. Thousands of illegal third country nationals are said to cross the Green Line, of which many of them have requested asylum in the Republic of Cyprus. This has led to a consequent increase in asylum application numbers (EUROPEAN COMMISSION (COM) 2005).

Besides commercial and labour crossborder interaction, people from the north increasingly cross to make use of the well developed public sector in Greek Cyprus. Ambulances cross the checkpoint to bring ill patients to Greek Cypriot hospitals. According to HAzou (2005) and official statistics, over 12,000 Turkish Cypriots, for example, received treatment between January and November 2004.

In addition, more and more students are crossing over to the south to study at Greek Cypriot universities in order to gain an internationally recognised degree. At the same time, people from the south cross over to go to cheaper dentists and buy cheaper food. Many commercial shops in the north now accept both currencies, both the Turkish Lira and the Cypriot Pound. First signs of gentrification have also become visible in the old city near the mosque, and the first trendy bars have opened their doors in the north.

But perhaps the greatest motivation for crossing the border is the better access to Europe and European citizenship through application for a Greek Cypriot passport. All of this has left a noticeable mark on Turkish Cypriot society. Home in north Nicosia meant for a long time what SAID observed as

«the unhealable rift forced between a human being and a native place, between the self and its true home: its essential sadness can never be surmounted» (2000: 173).

North Nicosia was a place which almost did not exist. Now blood seems to be flowing through its veins. It still is neither a country, nor a federal region, nor a colonial territory, and it is denied existence on any non-Turkish Cypriot map. It still has no postal code, nor co-ordinates for air or sea traffic, except with Turkey. Northern Cyprus has been denied access to history, being seen in retrospect simply as a place occupied by the Turkish Army. But now this part of the island is profiting from the Green Line: the buffer zone that was for a long time seen as a security necessity has become a line of opportunity. It is no longer solely associated with a constant state of insecurity, in-betweenness and precarious temporality.

\section{The road ahead}

The present situation in Nicosia would possibly have led to a scenario of unification or at least some sort of positive breakthrough if it had been dealt with at a geopolitical expert meeting twenty years ago. However, the opposite is currently the case. Conflicting discourses and conflicts of interests are still highly visible. However, it would seem that beyond the deadlock of the conflicting geopolitical discourses, the road ahead is positive. Nicosia, and with it Cyprus, appears to have developed an identity that breaks away from the domination of the dead zone of no man's land. Now, increasingly, a new on-theground-reality is being created and a new meaning of border as line of opportunity is being provoked. This change calls for a redefinition of this unique and unusual contra intervention of north «non-western» Nicosia within the long-standing and mutually entangled relationship of western and non-western urban modernities throughout much of the contemporary world. It is argued here that this new map of subterranean affiliations binding eastern and western urban modernities together as part of a fragmented, conflictual but nevertheless coherent system, can function as a breeding space for future interaction. Despite official attempts from both sides to generate contemporary geopolitical discourses and spaces of included-exclusion, it indeed (re)produces newly invigorated "political societies», but with the great difference that contemporary spaces of includedinclusion have been generated in northern Nicosia (Chatterjee 2004; Gilroy 2005; Pratt 1992). It has also been argued that the new-born on-the-ground and grassroots realities and newly created spaces of opportunity after 2004 have invoked a new political reality beyond the official domain. For this reason, it seems important to shed light on these newly arising shadow spaces, these voices unheard, these «hidden» trajectories of urban osmosis, created and enforced in the light of the EU membership of Cyprus. It appears equally necessary to assess the long-term impact of the porous Green Line on the fabric of the city of Nicosia, and the capacity for adaptation, co-optation and resistance, through new spectacles.

\section{Acknowledgement}

This research has been funded by the EU's $5^{\text {th }}$ framework research grant (EXLINEA, project number HPSE-CT-2002-00141).

\section{References}

Abu-Lughod, J.L. (1999): New York, Chicago, Los Angeles: America's global cities. - Minneapolis: University of Minnesota Press. 
BAHCELI, S. (2004): Economy in the north is booming. - In: Cyprus Mail, internet edition, October 12.

BAHCELI, S. (2005): Abandoned by the EU. - In: Cyprus Mail, internet edition, September 25.

Brown, L.C. (eds) (1973): From madina to metropolis: heritage and change in the Near Eastern city. - Princeton, NJ: The Darwin Press.

Chatterjee, P. (2004): The politics of the governed: popular politics in most of the world. - New York: Columbia University Press.

Cyprus Mail (2006): Mr Talat: please take down the bridge and open Ledra. - In: Cyprus Mail, internet edition, February 5.

European Commission (COM) (2005): Report on the implantation of Council Regulation (EC) 866/2004 of 29 April 2004 and the situation resulting from its application (COM, 2005). - Brussels, published February 5, 2006.

FANON, F. (1961): The wretched of the Earth. - New York: Grove Press.

GilroY, P. (2005): Postcolonial melancholia. - New York: Columbia University Press.

Graham, S. (ed.) (2004): Cities, war, and terrorism: towards an urban geopolitics. - Oxford: Blackwell.

GrEGORY, D. (2004): The colonial present: Afghanistan, Palestine, Iraq. - Oxford: Blackwell.

GrUNDY-WaRR, C. (2002): Cross-border regionalism through a «South-east Asian» looking-glass. - In: Space \& polity 6, 2: 215-225.

Hazou, E. (2005): Money pouring into the north. - In: Cyprus Mail, internet edition, January 18.

O'Toole, F. (1990): A mass for Jesse James: A journey through 1980s Ireland. - Dublin: Raven Arts.

O'Toole, F. (1997): The lie of the land. - London, New York: Verso.

PratT, M.L. (1992): Imperial eyes: travel writing and transculturation. - London: Routledge.

Republic of Cyprus (2006): Press and Information office, http://www.moi.gov.cy/moi/pio/pio.nsf/releases_ en $/$ releases_en? OpenDocument $\& \mathrm{y}=2006 \& \mathrm{~m}=5 \& \mathrm{e}=$ 28.11.2006.

SAID, E.W. (2000): Reflections on exile and other essays. - Cambridge, MA: Harvard University Press.

SANDERCOCK, L. (1998): Towards cosmopolis: planning for multicultural cities. - New York: John Wiley.

SAssen, S. (2001): The global city: New York, London, Tokyo. - Princeton, NJ: Princeton University Press.

Soja, E.W. (2000): Postmetropolis: critical studies of cities and regions. - Malden: Blackwell.

Summary: «The shadows of no man's land». Crossing the border in the divided capital city of Nicosia, Cyprus

In May 2004, only Greek Cyprus joined the European Union. The EU did not negotiate with Northern Cyprus as the Greek Cypriot government is acknowl- edged as sole representative of Cyprus. Despite this, after more than two years of EU membership, the Republic of Cyprus is seen in a positive light by the people of Northern Cyprus. Through the grey zone of the acquis communautaire, north Nicosia and Cyprus profit from European modernisation and the common market. Although the northern part of the island is still often labelled as "occupied territory», in the light of recent European developments, Nicosia, and with it Cyprus, seem to no longer be solely defined by their Green Line. This grey, self-created option means that the EU has indeed had a significant effect on the "Cyprus issue». For the Greek Cypriot authorities, their hoped-for advantage of a stronger negotiation position in Europe did not turn out as expected. For the north, their fragile socio-economic structures appear to have benefited from the common market with the Republic of Cyprus. Despite the current partitioning of Nicosia, this city may therefore be understood today as a unique example of urban osmosis. The conclusion is made that both the long-term impact of the new osmosis which is taking place at street level in the city of Nicosia, and the city's capacity for co-optation and resistance, should be assessed and perceived not in the form of traditional geopolitical narratives, but in a form more sensitive to its complex context.

\section{Zusammenfassung: «Schatten des Niemandslandes» in Nicosia. Überquerung der Grenze in der geteilten Hauptstadt Zyperns}

Im Mai 2004 trat nur der griechische Teil Zyperns der Europäischen Union bei. Somit wurde die griechisch-zypriotische Regierung als alleinige Vertretung Zyperns anerkannt. Nach mehr als zwei Jahren Mitgliedschaft in der EU ist nun auch die Republik Zypern für den türkischen Norden der Insel von Bedeutung. Durch die Grauzonen des acquis communautaire profitieren auch der Norden Nicosias und Zyperns von der europäischen Modernisierung und dem gemeinsamen Markt. Der nördliche Teil der Insel wurde oft als «besetztes Gebiet» bezeichnet. In Anbetracht der jüngsten europäischen Entwicklungen scheinen Nicosia und mit ihm Zypern allerdings nicht mehr allein durch die Green Line (grüne Grenzlinie) definiert zu sein. Diese selbst geschaffene Option deutet darauf hin, daß die EU tatsächlich eine prägende Wirkung auf das Zypernproblem hatte. Für die griechisch-zypriotische Regierung brachte der EUBeitritt nicht den erhofften Vorteil einer verbesserten Verhandlungsposition in Europa. Zudem scheinen die fragilen sozioökonomischen Strukturen des Nordens vom gemeinsamen Markt der Republik Zypern zu profitieren. Trotz der nach wie vor existierenden Teilung könnte man Nicosia als einen einzigartigen Fall von städtischer Osmose bezeichnen. Es wird gefolgert, $\mathrm{da} ß$ die langfristige Wirkung dieser neuen Osmose, die in den Strassen Nicosias stattfindet, und die Fähigkeit 
zu Vereinnahmung und Widerstand über die üblichen geopolitischen Narrative hinausgehen und aus einer speziellen Perspektive betrachtet werden sollten.

Résumé: «Les ombres du no man's land». Traverser la frontière dans la capitale divisée de Nicosie (Chypre)

En mai 2004, seule la partie grecque de l'île de Chypre - nommée officiellement République de Chypre - a rejoint l'Union européenne (UE). Son gouvernement fut alors reconnu comme l'unique représentant de Chypre. Cependant, le rattachement de la République de Chypre a également eu des conséquences pour les populations de la République turque de Chypre du Nord. Grâce aux acquis communautaires, le nord de la ville de Nicosie et de Chypre profitent également de la modernisation européenne et du marché commun. Bien que le nord de l'île soit souvent qualifié de «territoire occupé», à la lumière des développements européens récents, Nicosie et Chypre ne sont plus uniquement définis par l'existence de la Ligne verte séparant les deux entités. Les initiatives locales montrent que l'Union européenne a eu un effet important sur Chypre dans son ensemble. Pour les autorités chypriotes grecques, les espoirs placés dans la construction européenne n'ont pas été à la mesure de leurs espérances. En outre, les fragiles structures socio-économiques du nord semblent bénéficier du marché commun réalisé en République de Chypre. Malgré sa partition actuelle, Nicosie peut aujourd'hui être considérée comme un exemple d'osmose urbaine. C'est pourquoi l'article conclut en relevant que les effets à long terme de cette évolution à Nicosie, de même que les capacités de cooptation et de résistance qui s'y manifestent, ne peuvent plus être appréhendés selon une lecture géopolitique traditionnelle, mais selon une perspective renouvelée.

Dr. Freerk Boedeltje, Dr. Henk van Houtum, Dr. Olivier Thomas Kramsch, Nijmegen Centre for Border Research, Department of Geography, Radboud University Nijmegen, P.O. Box 9108, NL-6500 HK Nijmegen, The Netherlands.

e-mail:

f.boedeltje@fm.ru.nl

h.vanhoutum@fm.ru.nl

o.kramsch@fm.ru.nl

Manuskripteingang/received/manuscrit entré le 11.7.2006

Annahme zum Druck/accepted for publication/accepté pour l'impression: 26.2 .2007 